\title{
New species of the genus Leporinus Agassiz (Characiformes: Anostomidae) from the rio Curuá, rio Xingu basin, Serra do Cachimbo, Brazil, with comments on Leporinus reticulatus
}

\author{
José L. O. Birindelli and Heraldo A. Britski
}

\begin{abstract}
A new species of Leporinus Agassiz is described from the rio Curuá, a tributary of the rio Iriri, rio Xingu basin, Serra do Cachimbo, Pará State, Brazil. The new species is diagnosed by the color pattern, which consists of eight to ten midlateral round dark blotches plus 20 to 40 smaller ones scattered over the body, dental formula 3/4, subinferior to inferior mouth, 37 to 38 lateral line scales, 4/3-4 transversal series of scales, and 12 circumpeduncular scale series. The new species most closely resembles L. octomaculatus and L. reticulatus from the upper Tapajós basin, and L. marcgravii and L. microphthalmus from the rio São Francisco and the rio Paranaíba, respectively. Based on recently collected specimens, L. reticulatus is re-diagnosed as having an allometric elongation of the snout.
\end{abstract}

Uma nova espécie de Leporinus Agassiz é descrita do rio Curuá, um tributário do rio Iriri, bacia do rio Xingu, na Serra do Cachimbo, Pará, Brasil. A nova espécie é diagnosticada pelo padrão de colorido, que consiste de oito a dez manchas escuras arredondadas sobre a linha lateral e mais 20 a 40 manchas menores sobre o corpo, fórmula dental 3/4, boca subinferior a inferior, 37 a 38 escamas na linha lateral, 4/3-4 séries transversal de escamas, e 12 séries de escamas circumpedunculares. A nova espécie se assemelha a L. octomaculatus e L. reticulatus da bacia do alto Tapajós, e L. marcgravii e L. microphthalmus do rio São Francisco e rio Paranaíba, respectivamente. Com base em espécimes recentemente coletados, L. reticulatus é rediagnosticada como tendo um crescimento alométrico do focinho.

Key words: Leporinus guttatus, Taxonomy, Hypomasticus, Ostariophysi.

\section{Introduction}

Leporinus Agassiz is one of the most species-rich genera in the entire order Characiformes, with approximately 90 valid species (Britski \& Garavello, 2003, 2005; Britski \& Birindelli, 2008; Santos \& Zuanon, 2008). Although several species have been described in the last twenty years (see Britski \& Garavello, 2003), recent collection efforts in streams and small tributaries of large river drainages, especially in the Amazon basin, have revealed a still greater number of undescribed species.

Fish collections from the Serra do Cachimbo, the highest portion of the Brazilian shield in the Amazon, have revealed a quite rich and endemic fish fauna (Lima \& Birindelli, 2006; Birindelli et al., 2009). The area is drained by three major river basins, the rio Curuá, a large tributary of the rio Iriri in the rio
Xingu basin, and the rio Teles Pires and the rio Jamanxim, flowing into the rio Tapajós. The rio Curuá near Vila de Cachoeira da Serra (approximately at $08^{\circ} 44^{\prime} \mathrm{S} 54^{\circ} 58^{\prime} \mathrm{W}$ ) drop off from Serra do Cachimbo tablelands in a series of two great waterfalls of approximately 40 and 60 meters deep, separated only by a 50 meters river stretch, that completely isolate the fish fauna in the areas above the falls (Goulding et al., 2003).

During a recent expedition to the Serra do Cachimbo, an undescribed species of Leporinus was discovered from the rio Curuá. The undescribed species most closely resembles $L$. reticulatus Britski \& Garavello, 1993 and L. octomaculatus Britski \& Garavello, 1993, both described from the upper rio Tapajós basin, L. marcgravii Lütken, 1875, from the rio São Francisco and L. microphthalmus Garavello, 1989 from the rio Paranaíba (upper rio Paraná basin).

Large specimens of Leporinus reticulatus, a species

Museu de Zoologia da Universidade de São Paulo, Caixa Postal 42494, 04218-970 São Paulo, SP, Brazil. josebirindelli@yahoo.com; heraldo@usp.br 
described based on small specimens, recently collected in the Tapajós basin revealed an unusual snout elongation, and color pattern variation previously unknown for the species.

The aim of the present contribution is to describe the new species, and re-diagnose L. reticulatus based on recently collected material.

\section{Material and Methods}

Counts and measurements were taken according to Britski \& Garavello (1978) and Winterbottom (1980). Meristic data are given in the description, with the frequency of each count provided in parentheses after the respective count, and an asterisk indicating counts of the holotype. Lateral line scale counts included the pored scales extending onto base of the median caudal-fin rays. The upper transversal series of scales is represented by the number of rows of scales between the lateral line and the dorsal-fin origin (counting neither the scale on the middorsal series immediately anterior to the dorsal-fin origin, nor the small scale at the base of the anteriormost dorsal-fin rays); this procedure always eliminates the very confusing count of a half scale in this series. A half scale between the lateral line and pelvic-fin origin is only counted when the base of pelvic-fin first ray faces anteriorly the middle of the scale immediately in front of it. Tooth counts are expressed as dental formula and represents the premaxillary number of teeth over the dentary in each half of the jaw. Vertebral counts were taken only from x-rayed specimens; vertebrae of the Weberian apparatus were counted as four elements, included in the vertebral counts, and the fused PU1+U1 of the caudal region as a single element. The pattern of circuli and radii was defined on scales sampled from region between the lateral line and the base of dorsal fin. Scanning electron microscopy (SEM) images of the premaxilla, dentary and its teeth were taken from cleared and double stained paratype (cs), prepared according to the method of Taylor \& Van Dyke (1985). All examined material is alcohol preserved, except when indicated by cs or sk for dry skeleton. Institutional abbreviations includes: MZUSP, Museu de Zoologia da Universidade de São Paulo, São Paulo, ANSP, Academy of Natural Sciences of Philadelphia, Philadelphia, and INPA, Instituto Nacional de Pesquisas da Amazônia, Manaus.

\section{Results}

\section{Leporinus guttatus, new species}

Figs. 1, 2

Holotype. MZUSP 97100, 107.5 mm SL, Brazil, Altamira, rio Curuá, Iriri drainage (rio Xingu basin), upstream from PCH (=small hydroeletric dam) Buriti, 0846’28'S 545'12”W, 21 Oct 2007, J. L. O. Birindelli, L. M. Sousa, A. Netto-Ferreira, M. H. Sabaj Pérez, N. Lujan.

Paratypes. Brazil, Pará, Altamira, Iriri drainage (rio Xingu basin). ANSP 189166, 1, 106.4 mm SL; INPA 30761, 1, $103.1 \mathrm{~mm} \mathrm{SL}$; MZUSP 99741, 5, 84.8-107.5 mm SL; collected with holotype. MZUSP 96865 (11, 70.6-108.5 mm SL, $1 \mathrm{cs,} 96.5 \mathrm{~mm} \mathrm{SL})$, rio

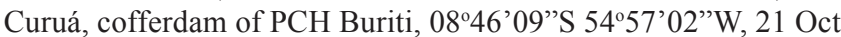
2007, J. L. O. Birindelli et al. MZUSP 101300 (11, 96.4-124.7 mm SL, 2 sk, approximately $100 \mathrm{~mm}$ SL), rio Curuá, 0845'55”S 5457'04’W, 23 Jan 2009, J. L. O. Birindelli et al.

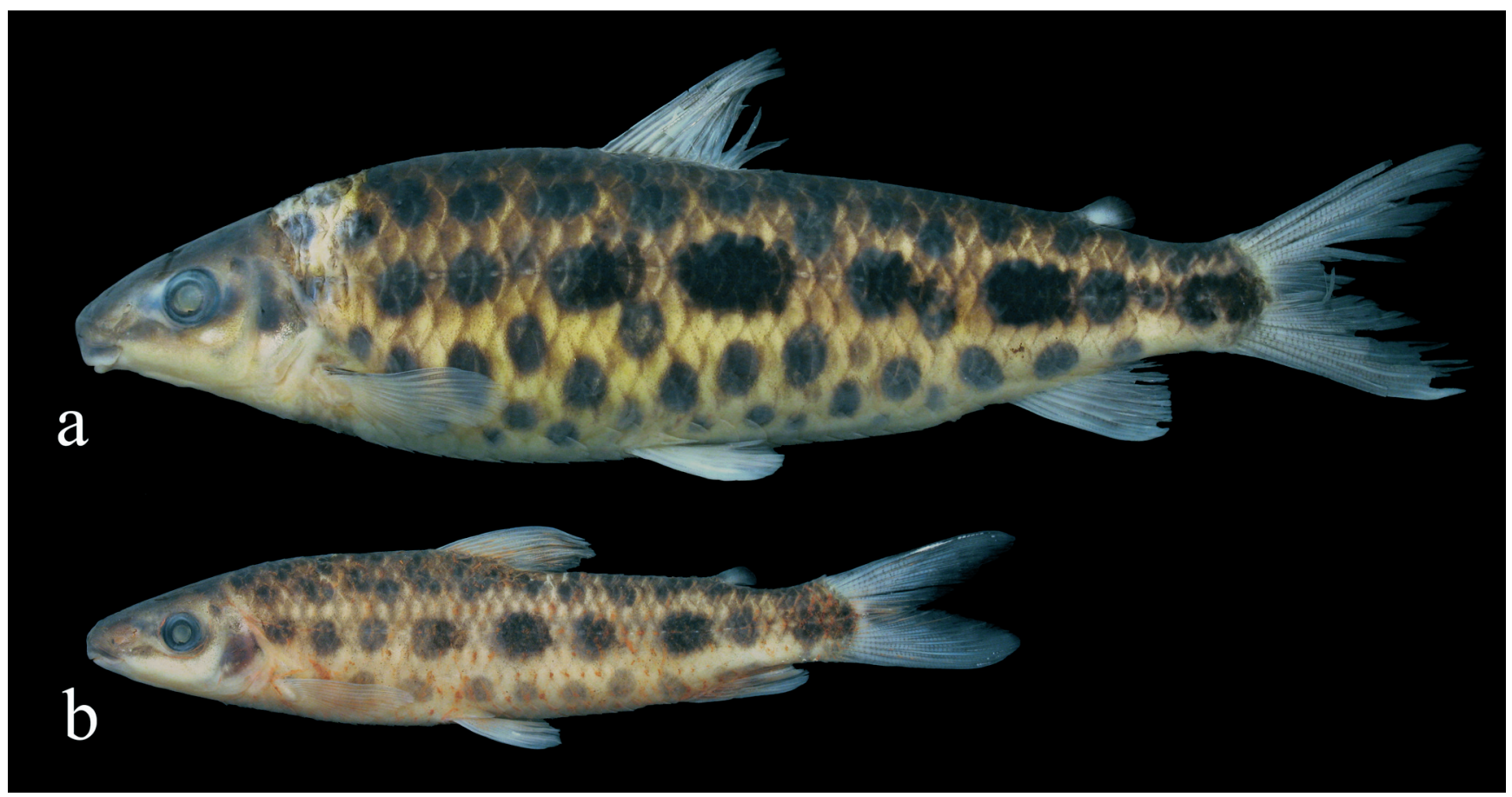

Fig. 1. Leporinus guttatus, a - holotype, MZUSP 97100, 107.5 mm SL, b - paratype, MZUSP 96865, 81.3 mm SL, Brazil, Altamira, Pará State, rio Curuá. 
Diagnosis. Leporinus guttatus is diagnosed by its unique coloration, which consists of eight to ten midlateral round dark blotches, and 20 to 40 smaller ones forming one or two irregular series above and two or three irregular series below midlateral blotches.

Leporinus guttatus can be further distinguished from its congeners, except $L$. amae, L. bahiensis, L. bistriatus, $L$. garmani, L. marcgravii, L. megalepis, L. melanopleura, $L$. microphthalmus, L. octofasciatus, L. octomaculatus, $L$. paranensis, $L$. reticulatus, $L$. sexstriatus, $L$. striatus, $L$. taeniatus, L. taeniofasciatus, L. tigrinus, and L. uatumaensis by the dental formula $3 / 4$ ( $v s$. dental formulae $3 / 3,4 / 4$ or $4 / 3$ ). Leporinus guttatus is distinguished from $L$. bahiensis, $L$. megalepis, L. melanopleura, L. octofasciatus, L. paranensis, L. striatus, L. taeniatus, L. taeniofasciatus, L. tigrinus, and L. uatumaensis by having 12 circumpeduncular scale series (vs. 16). Leporinus guttatus differs from L. amae, L. bistriatus, L. sexstriatus, and L. garmani by the presence of dark blotches on body (vs. dark longitudinal stripes in L. amae, $L$. bistriatus, L. sexstriatus, and only one dark blotch on caudal peduncle in $L$. garmani). Leporinus guttatus differs from $L$. marcgravii, L. octomaculatus, and L. microphthalmus by the presence of eight to ten dark midlateral blotches on body ( $v s$. six to eight large midlateral dark blotches over body), two or three irregular series of smaller dark blotches below the midlateral ones ( $v s$. one) and, when compared to $L$. octomaculatus, by relatively short head in specimens larger than $90 \mathrm{~mm}$ SL (20.9-22.7, mean 21.7, $\mathrm{n}=10$; vs. 22.1-24.8, mean 23.1, $\mathrm{n}=18$ ). Leporinus guttatus is distinguished from L. reticulatus by the presence of round dark blotches on body ( $v s$. irregular dark blotches), mouth subinferior to inferior ( $v s$. subterminal to subinferior), and shorter head length (20.9 to 23.6 , mean 22.3 ; vs. 26.0 to 30.8 , mean 27.7).

Description. Morphometric data of holotype and paratypes in Table 1. Relatively small size, when compared to congeners, largest examined specimen $124.7 \mathrm{~mm}$ SL. Body elongate and moderately compressed. Dorsal profile gently convex from snout tip to dorsal-fin origin, straight from dorsal-fin origin to adipose-fin origin, and distinctly concave from adipose-fin origin to anteriormost dorsal caudal-fin procurrent rays. Ventral profile distinctly convex from lower jaw to posterior insertion of anal-fin rays, and gently concave from this point to origin of lower lobe of caudal-fin. Greatest body depth at dorsal-fin origin. Head somewhat compressed.

Mouth subinferior (reaching slightly ventrally to longitudinal through lower margin of orbit, in specimens around $80 \mathrm{~mm} \mathrm{SL}$ ) to inferior (reaching slightly ventrally to longitudinal through lower margin of infraorbitals, in specimens of $90 \mathrm{~mm}$ SL or more). Snout rounded to slightly acute in some specimens (as in holotype, see Fig.1a). Premaxilla with three incisiform teeth gently diminishing in size from symphyseal tooth. Dentary with four incisiform teeth also gradually decreasing in size laterally (Fig. 3).

Dorsal fin ii, 10 (20), origin slightly in front of vertical through pelvic-fin origin; fin-base six scales in length, distal margin convex. Pectoral fin i,13 (2), 14* (9), 15 (6) or 16 (3), extending through five to six scales from fin base, distal margin convex. Pelvic fin i,8 (20), extending through five scales, distal margin convex. Anal fin ii, 8 (20), anal-fin origin at vertical through fifth scale anterior to adipose-fin origin; adpressed fin not reaching base of lower caudal-fin rays, distal margin straight or slightly convex. Caudal-fin rays i, $8,9, \mathrm{i}(20)$, forked, lobes rounded, upper lobe slightly more elongate than lower lobe. Vertebrae 35 (2) to 36 (4).

Scales with 5 to 7 radii. Lateral line complete with 37 (14) or 38* (6) perforated scales. Transversal series with 4 (20) scales from dorsal-fin origin to lateral line; 3 (12), 3.5 (6) or 4 * (2) scales from lateral line to pelvic-fin base; and 3 (16) or 3.5* (4) scales from lateral line to anal-fin base. Predorsal scales 10 (5) or $11 *(15)$. Twelve horizontal scale rows around caudal peduncle.

Coloration. Overall ground color tan. Head and body slightly countershaded, gradually darker above longitudinal line from mouth, through lower border of orbit to midline of opercle, and body above lateral line. Body with eight to ten dark round blotches along lateral line, three of them slightly larger and more conspicuous (one below posterior insertion of dorsal fin, one above anal-fin origin and one on caudal peduncle),

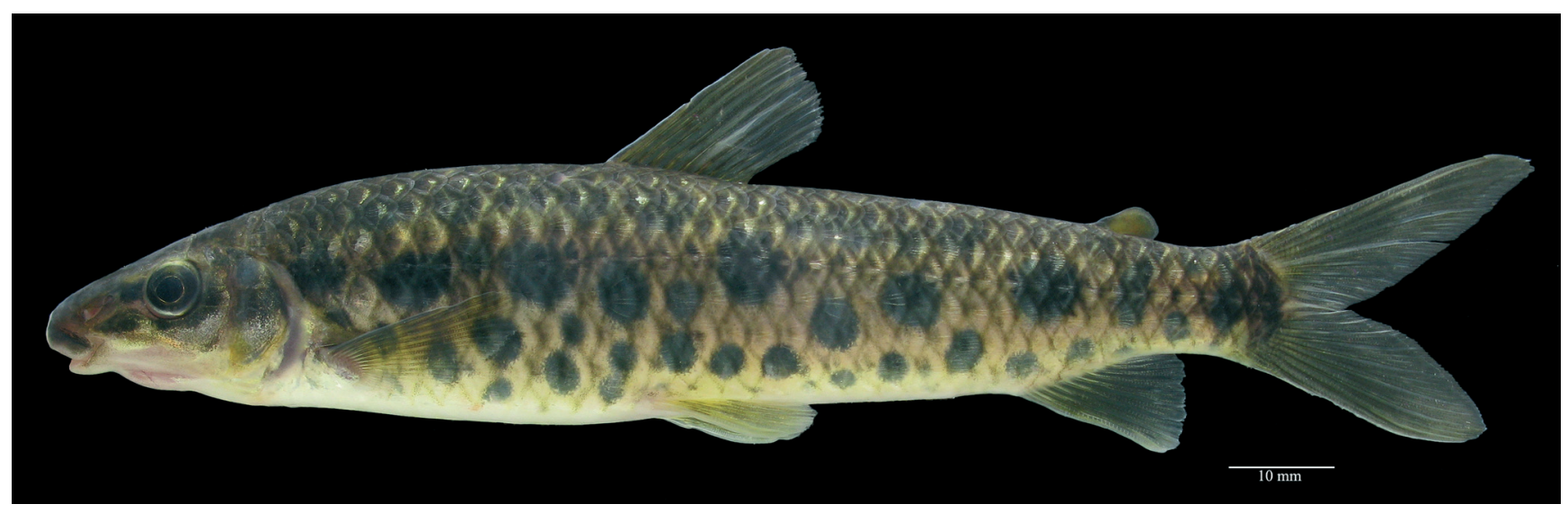

Fig. 2. Leporinus guttatus, live specimen, paratype, MZUSP 101300, 124.7 mm SL. 


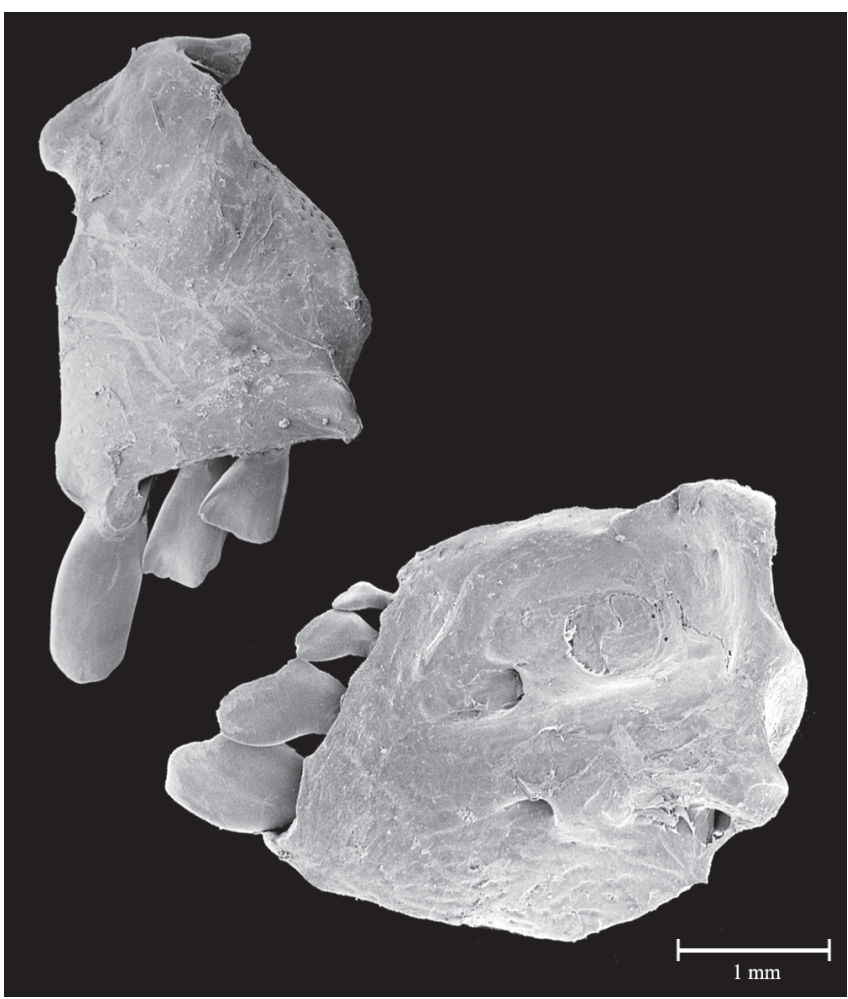

Fig. 3. Leporinus guttatus, paratype, MZUSP 96865, $96.5 \mathrm{~mm}$ SL. Upper and lower jaws, in frontal and lateral views respectively.

and several (about 20 to 40) smaller blotches scattered over body. Smaller specimens, up to $80 \mathrm{~mm} \mathrm{SL}$, with fewer (around 20) smaller blotches forming one or two irregular series above and two or three irregular series below midlateral blotches (Fig. 1b). Larger specimens, from $90 \mathrm{~mm}$ SL, with more numerous (around 40) smaller blotches forming two to three irregular series below and above midlateral blotches (Fig. 1a). Ventral surfaces of head and body pale yellow to cream, without chromatophores. Adipose fin with dark distal margin. Remaining fins nearly hyaline, with few chromatophores along margins of rays.

Live coloration as describe above, except for overall ground coloration more tan than yellow (Fig. 2).

Geographic distribution. Leporinus guttatus is known from the upper rio Curuá, above the great falls of Serra do Cachimbo (Figs. 4 and 5). The rio Curuá is a tributary to the rio Iriri, a large tributary to the lower rio Xingu. The absence of L. guttatus from collections made below the waterfalls indicates that the new species might be restricted to the river portion isolated above the falls (see Birindelli et al., 2009 for discussion on the endemism of the upper rio Curuá Ichthyofauna).

Ecological notes. Specimens of Leporinus guttatus were caught in a clear water stream, near waterfalls (MZUSP 97100 and MZUSP 101300) or in a cofferdam just above a waterfall (MZUSP 96865). Fishes were caught most effectively by gill nets and cast net during the sunset.
Table 1. Morphometric data for Leporinus guttatus. SD = Standard Deviation.

\begin{tabular}{lccccc}
\hline & $\mathrm{n}$ & Mean & Range & SD & Holotype \\
\hline Standard Length (mm) & \multicolumn{5}{c}{$730.6-124.7$} \\
& Percents of standard length & & 107.50 \\
Predorsal distance & 20 & 46.69 & $45.47-47.74$ & 0.65 & 46.14 \\
Dorsal-fin origin to adipose-fin & 20 & 39.32 & $37.05-41.32$ & 1.36 & 40.65 \\
origin & 20 & 48.11 & $45.66-49.72$ & 1.02 & 47.26 \\
Prepelvic distance & 20 & 22.80 & $20.67-25.69$ & 1.43 & 25.30 \\
Body depth & 20 & 9.24 & $8.74-9.79$ & 0.28 & 8.84 \\
Caudal peduncle depth & 20 & 12.86 & $11.52-13.87$ & 0.60 & 12.84 \\
Caudal peduncle length & 20 & 16.19 & $13.83-18.23$ & 1.33 & 14.33 \\
Anal-fin lobe length & 20 & 22.30 & $20.93-23.58$ & 0.77 & 20.93 \\
Head length & Percents of head length & & \\
& 20 & 77.60 & $74.53-80.00$ & 1.21 & 78.22 \\
Preopercle length & 20 & 41.38 & $38.86-44.15$ & 1.45 & 40.00 \\
Snout length & 20 & 77.66 & $72.49-82.13$ & 2.74 & 81.78 \\
Head depth & 20 & 23.12 & $20.43-25.97$ & 1.34 & 23.11 \\
Eye diameter & 20 & 34.21 & $31.00-37.45$ & 1.56 & 34.67 \\
Bony interorbital & \multicolumn{5}{c}{}
\end{tabular}

Etymology. From the latin guttatus, meaning spotted or dappled, in allusion to the presence of the dark blotches scattered over the body, which are more numerous than those in any other known species of Leporinus. An adjective.

\section{Discussion}

Comments on the Leporinus guttatus. The genus Leporinus comprises a great number of species. During the last century, few studies have attempted to split the genus into smaller groups such as subgenus. Fowler (1914) created the subgenus Myocharax for L. desmotes, a species with terminal mouth and symphysal teeth greatly enlarged. Borodin (1929) created the subgenus Hypomasticus for L. mormyrops Steindachner, 1875 (type-species), L. garmani Borodin, 1929 and L. thayeri Borodin, 1929, noting however, that the mouth position in the latter was not as derived as in the first two species. Géry (1960a) redescribed $L$. despaxi recognizing it, along with $L$. mormyrops, L. garmani, L. thayeri, and L. crassilabris, in the subgenus Hypomasticus. However, Géry (1960a) noticed that Hypomasticus is an "entité taxonomique commode sans grande valeur phylogénétique”. Concomitantly, Géry (1960b) described the subgenus Leporinops, for L. moralesi, based on its terminal, almost upturned mouth and bicuspid symphyseal teeth on the premaxillary, discussing its possible relationship to Abramites. Later on, Géry (1977) recognized three subgenera in the genus Leporinus, in addition to the "subgenus typical Leporinus": Leporinops (with L. moralesi and L. jamesi), Myocharax (with L. desmotes), Hypomasticus (with L. mormyrops, L. thayeri, L. garmani, Leporinus "maculatus" (=L. megalepis), and L. despaxi). On a different approach, Britski \& Garavello (1978) recognized three species group within the genus Leporinus, according to adult color pattern: the barred species group (or "fasciatus group") diagnosed by having 8 to 12 transverse (straight or oblique) dark bars on body, the striped species group (or "striatus group") with one to six horizontal dark stripes, and the blotched species group (or "friderici group") with dark blotches over body, usually with three larger midlateral 


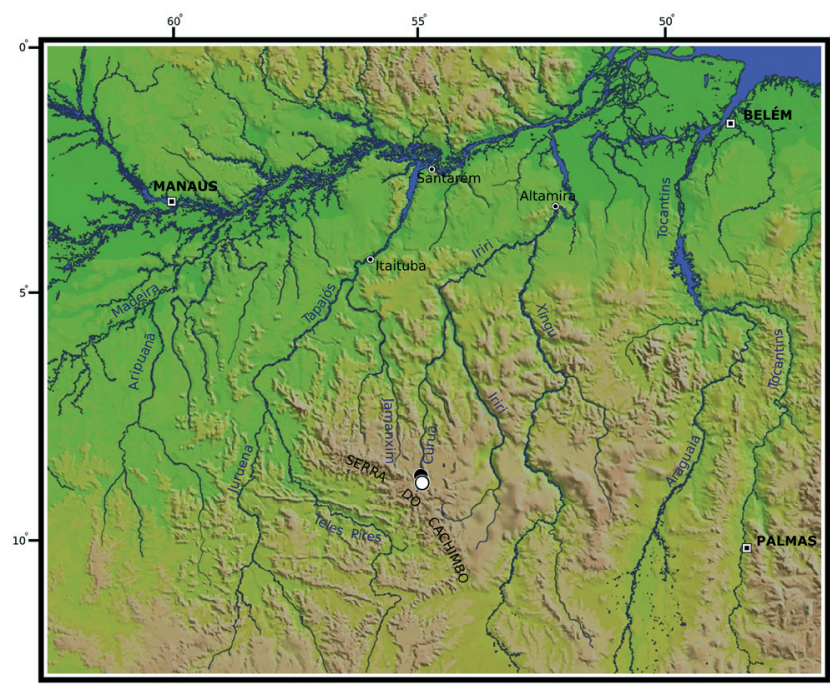

Fig. 4. Distribution of Leporinus guttatus in the rio Curuá, rio Xingu basin, central Brazil (type locality represented by open circle).

blotches, one ventral to the dorsal fin, another dorsal to the anal fin and last one on the caudal peduncle.

Recently, Sidlauskas \& Vari (2008) presented a comprehensive phylogenetic analysis focused on the relationships of the family Anostomidae. Their results are very robust for the relationships of the Anostomidae within Anostomoidea, and for the distalmost species included in Anostomoides, Rhytiodus, Schizodon, Laemolyta, and in the Anostominae (sensu Winterbottom, 1980). Furthermore, all genera of the family were confirmed as monophyletic, except for Leporinus. Sidlauskas \& Vari's (2008) analysis included few representatives (approximately $20 \%$ of the species) of the genus Leporinus (sensu Garavello \& Bristki, 2003). Three clades including species of that genus were recovered. The first, composed by L. despaxi, L. megalepis, L. mormyrops, and $L$. pachycheilus, was considered the second basalmost group within the family, and comprise the resurrected genus Hypomasticus. The second clade encompassed L. striatus and Abramites hypselonotus, and the third clade included the species assigned to the fasciatus group. In addition, a single species, L. pellegrinii were recovered as the sister taxon of Anostomoides and related genera (see above). Sidlauskas \& Vari (2008: 166) also assigned L. thayeri, L.julii and L. garmani to Hypomasticus, based on the examination of intact specimens (directly or by photograph).

The study on the morphology of Leporinus guttatus have revealed the presence of three of the four synapomorphies assigned to Hypomasticus, the vertically oriented premaxilla (\#46: 0), the wide ascending process of anguloarticular (\#55: 1 ), and the trough formed by the ascending process of the anguloarticular (\#56: 1). The other character assigned for Hypomasticus, the lateral process of anterior portion of mesethmoid (\#16:1), is absent in L. guttatus. On the other hand, at least two of the five unambiguous synapomorphies assigned to the clade composed by all remaning Anostomids, except Leporellus and Hypomasticus, are present in $L$. guttatus. In that species, the anterior margin of the antorbitals is positioned distinctly anterior of anterodorsal opening of sensory canal of first infraorbital (\#2: 1), and the ectopterygoid vertically oriented with vertical through anterodorsal limit of ectopterygoid passing through ventral portion of ectopterygoid (\#72: 1). This combination of characters makes it impossible to securely assign L. guttatus to either Hypomasticus or Leporinus (sensu Sidlauskas \& Vari, 2008). The same holds true for the species $L$. octomaculatus, $L$. reticulatus, L. microphthalmus and L. marcgravii, all similar to L. guttatus in many aspects (see below). Only through a

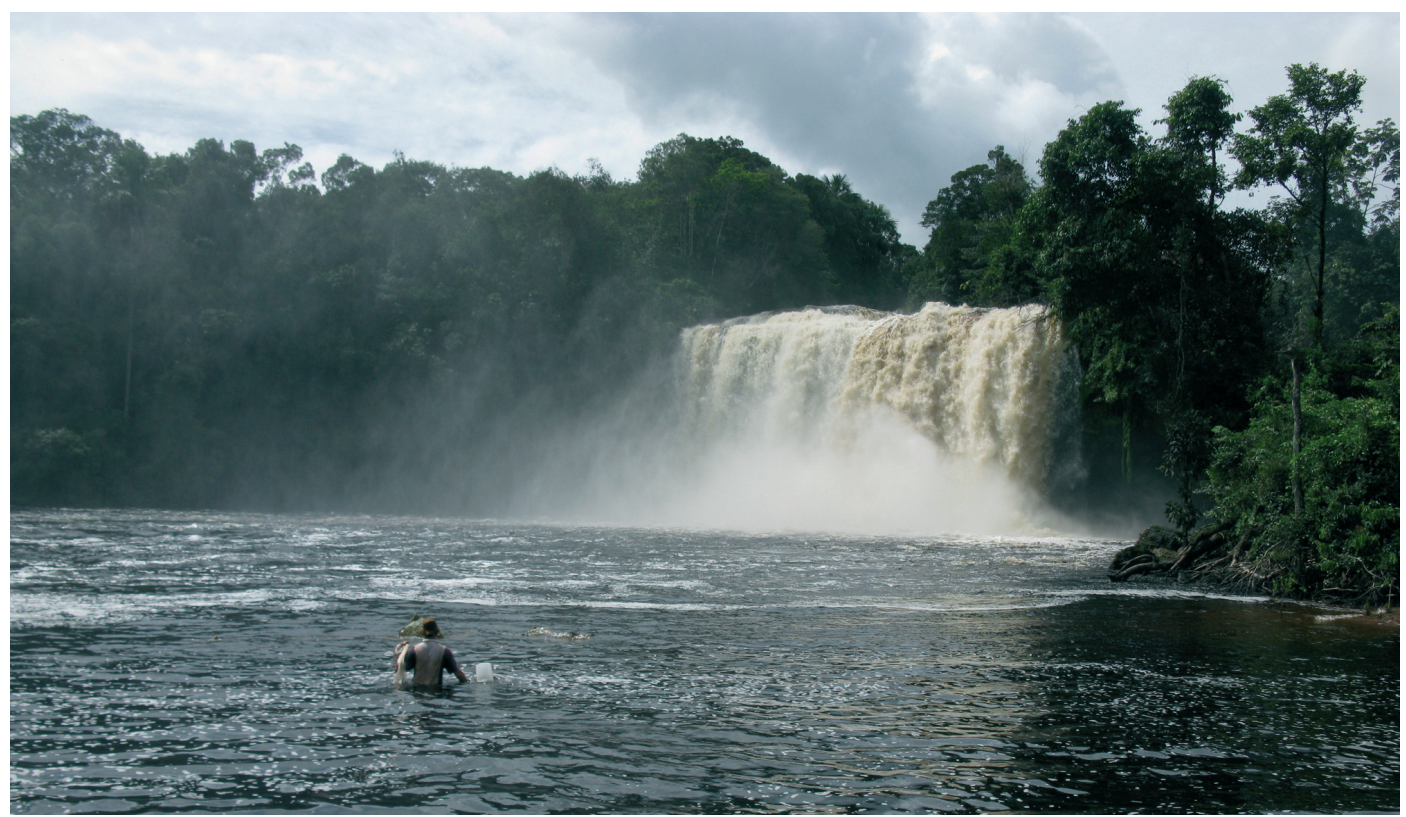

Fig. 5. Rio Curuá, above the great falls, showing one of the collection sites of Leporinus guttatus. 
phylogenetic analysis focused on the species of Leporinus, expanding the study of Sidlauskas \& Vari (2008) by the addition of more species of Leporinus, it will be possible to confidently establish the limits of the groups within the former genus Leporinus. Therefore, for the moment, we conservatively assign $L$. guttatus, and similar species, to the genus Leporinus (sensu Garavello \& Britski, 2003).

The meristic data (e.g., scale and tooth counts), and the general color pattern (more than three large midlateral dark blotches along the body) of L. guttatus are also present in $L$. marcgravii, L. microphthalmus, L. octomaculatus and $L$. reticulatus. Nevertheless, in $L$. reticulatus the dark blotches have different shapes and arrangements (Fig. 6), and the snout is elongate, especially in large specimens (see Comments on Leporinus reticulatus below). The other three species have similar color pattern to the new species, but the blotches are fewer and the largest ones (six to seven in L. marcgravii and L. microphthalmus, or eight in L. octomaculatus, see Fig. 7), are distinctly larger, similarly sized, and aligned over the lateral line, and there is only one series of smaller blotches below the lateral line (inconspicuous or absent in some specimens) and one to two above the lateral line.

Comments on Leporinus reticulatus. Leporinus reticulatus was described by Britski \& Garavello (1993) on the basis of 13 specimens from a single locality at riacho Formoso, a small creek in the rio Arinos drainage, in the upper rio Tapajós basin, Mato Grosso State. The specimens utilized for describing this uniquely colored species were very small, ranging from 38.2 to $72.5 \mathrm{~mm} \mathrm{SL}$, what let the authors to assume that this was a small sized species of Leporinus. In the last two years we have received collections of $L$. reticulatus from other localities in the upper rio Tapajós basin (see Comparative Material Examined), which included specimens up to approximately $140 \mathrm{~mm} \mathrm{SL}$. These larger specimens possess snout shape completely different, and color pattern slightly differ- ent from that of the type series of $L$. reticulatus. Therefore, those new specimens make a re-diagnosis of the species necessary.

Leporinus reticulatus is diagnosed by its unique color pattern characterized by a large number of dark blotches scattered on the body, blotches unequal in size and with irregular margins. Blotches usually arranged in transverse dark bars and disrupted by lighter markings in small specimens (up to $60 \mathrm{~mm}$ SL; Fig. 6b). In gradually larger specimens (60-80 mm $\mathrm{SL}$ ), bars fragmenting forming blotches that become separated and irregularly scattered in large specimens (from 80 mm SL; Fig. 6a). In some of the lots (MZUSP 99736), relatively small specimens (around $60 \mathrm{~mm} \mathrm{SL}$ ) already have the same color pattern as described for adults. In addition to the color pattern, L. reticulatus is diagnosed by an elongate snout (especially in larger specimens), snout length $35-50 \%$ (mean $43 \%$ ) of head length (snout length $47-50 \%$, mean $48 \%$, of head length, in specimens larger than $80 \mathrm{~mm} \mathrm{SL}$ ). Furthermore, $L$. reticulatus can be diagnosed by the following combination of subterminal (in specimens up to $100 \mathrm{~mm} \mathrm{SL}$ ) to subinferior (in specimens from $100 \mathrm{~mm} \mathrm{SL}$ ) mouth, dental formula $3 / 4,35$ to 37 scales in lateral line, 4/3.5-4.5 transversal series of scales, and 12 circumpeduncular scale series.

Noteworthy in Leporinus reticulatus is the allometric change in the length of snout. Gradually larger specimens (from $80 \mathrm{~mm} \mathrm{SL}$ ) undergo an elongation on the snout (comparatively much greater than associated structures, as for example, eye diameter). Figure 8 shows the allometric growth of the snout in relation to the SL in L. reticulatus. That change is also obvious when comparing snout proportions in two specimens of different sizes, for example, snout length $35 \%$ vs. $50 \%$ of head length, snout length $10 \%$ vs. $14 \%$ of SL, and eye diameter $77 \% v s .33 \%$ of snout length in a specimen of 42.5 (MZUSP 44782) and another of $135.6 \mathrm{~mm}$ SL (MZUSP 99736). Similar allometric development of the snout in any other Leporinus species was only noticed by Borodin (1929:

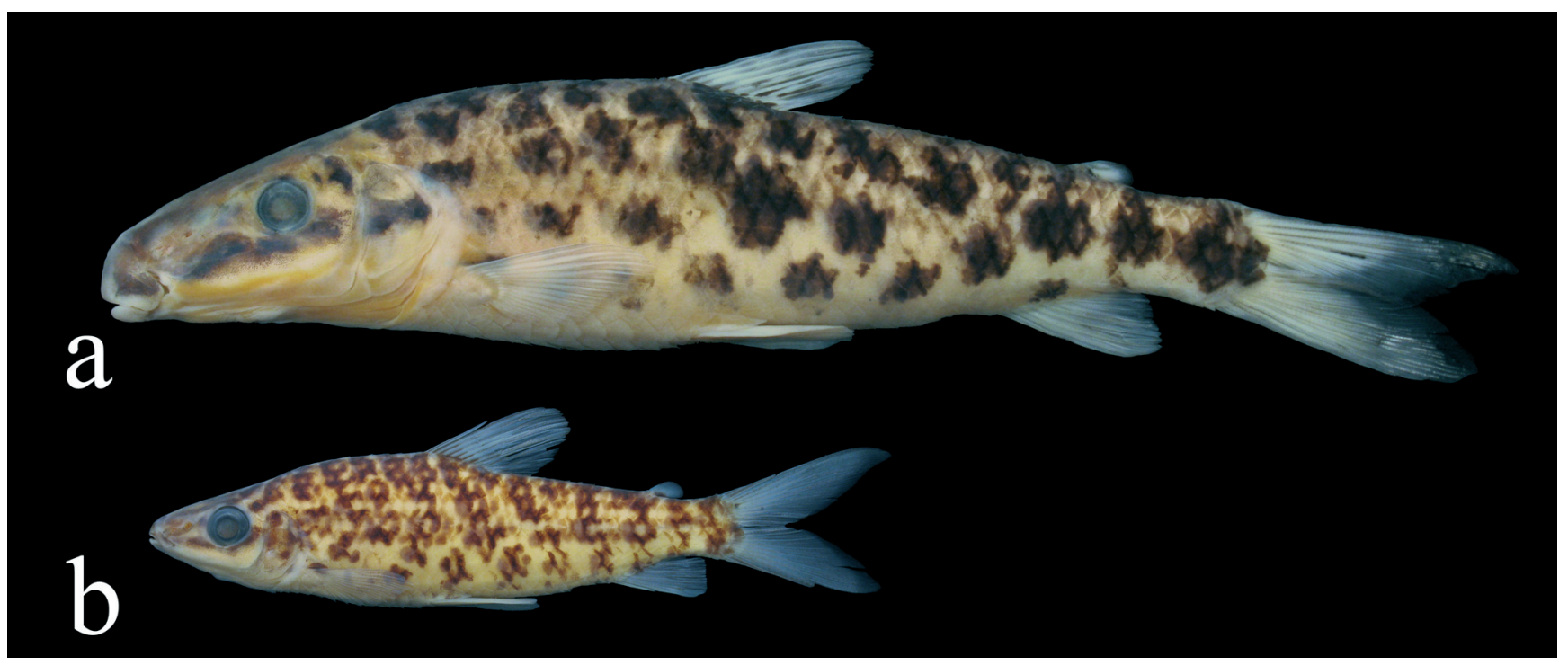

Fig. 6. Leporinus reticulatus, a - MZUSP 99736, 135 mm SL, b - holotype, MZUSP 44781, 66.2 mm SL. 
274-275), when he described L. crassilabris (see Borodin, 1929: plate 4 and fig. 1), but unlike L. reticulatus, L. crassilabris is a rather large-size species, reaching at least up to $420 \mathrm{~mm}$ SL.

The elongation of the snout in Leporinus reticulatus is associated to the elongation of the entire suspensorium, especially the hyomandibula, quadrate, metapterygoid and interopercle; the elongation of the antero-dorsal portion of the cranium, especially the mesethmoid; and the rearrangement of several bones, especially the first and second infraorbitals. In smaller specimens the first infraorbital is parallel to the body axis, and the associated second infraorbital is relatively oblique to the body axis, with its posterior portion more ventral and longer than anterior one (Fig. 9a). In larger specimens the first infraorbital shift to an oblique position in relation to the body axis, with the anterior portion
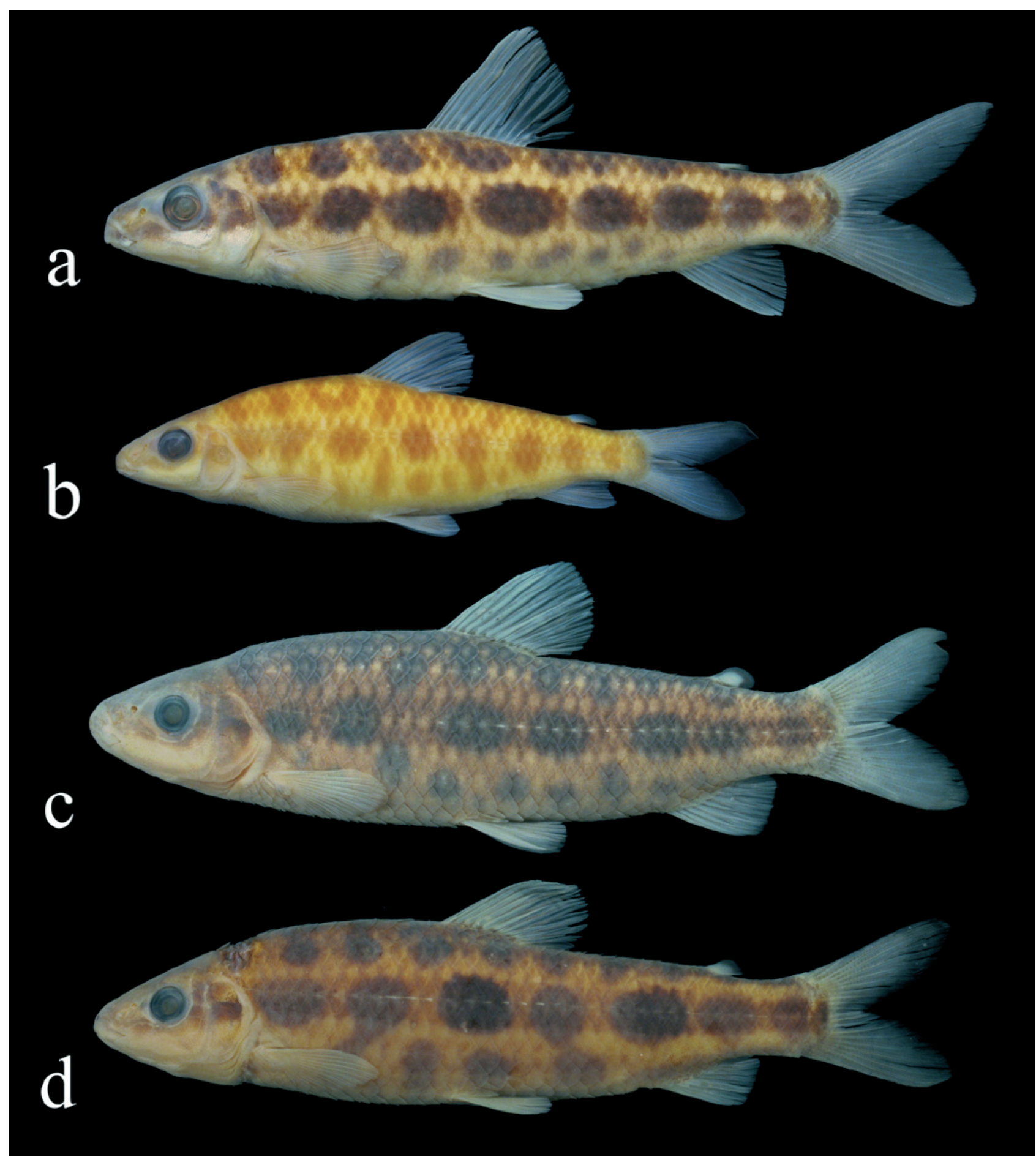

Fig. 7. Leporinus octomaculatus, a - MZUSP 78868, 94.4 mm SL, b - holotype, MZUSP 44794, 68.5 mm SL. L. marcgravii, cMNRJ 21587, 94.6 mm SL. L. microphthalmus, d-MCP 28230, 94.4 mm SL. 


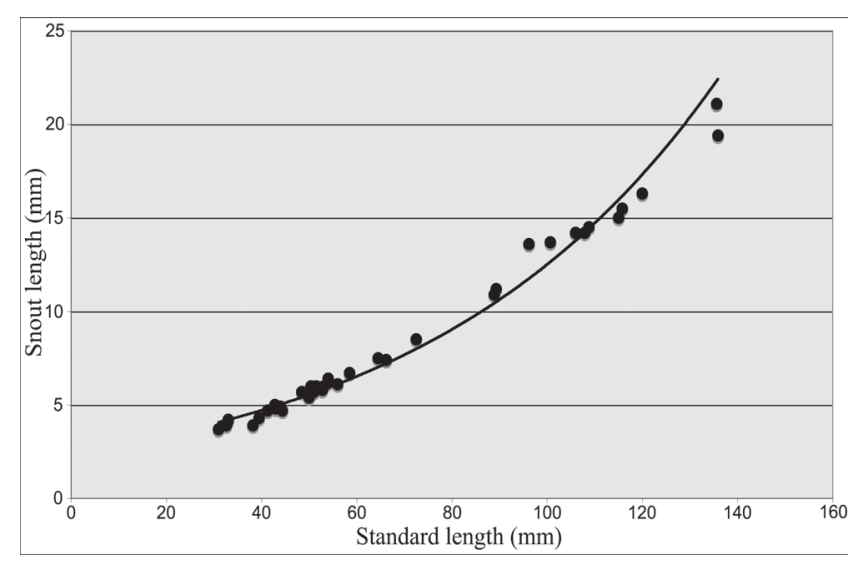

Fig. 8. Graph showing the ontogenetic elongation of the snout in Leporinus reticulatus.

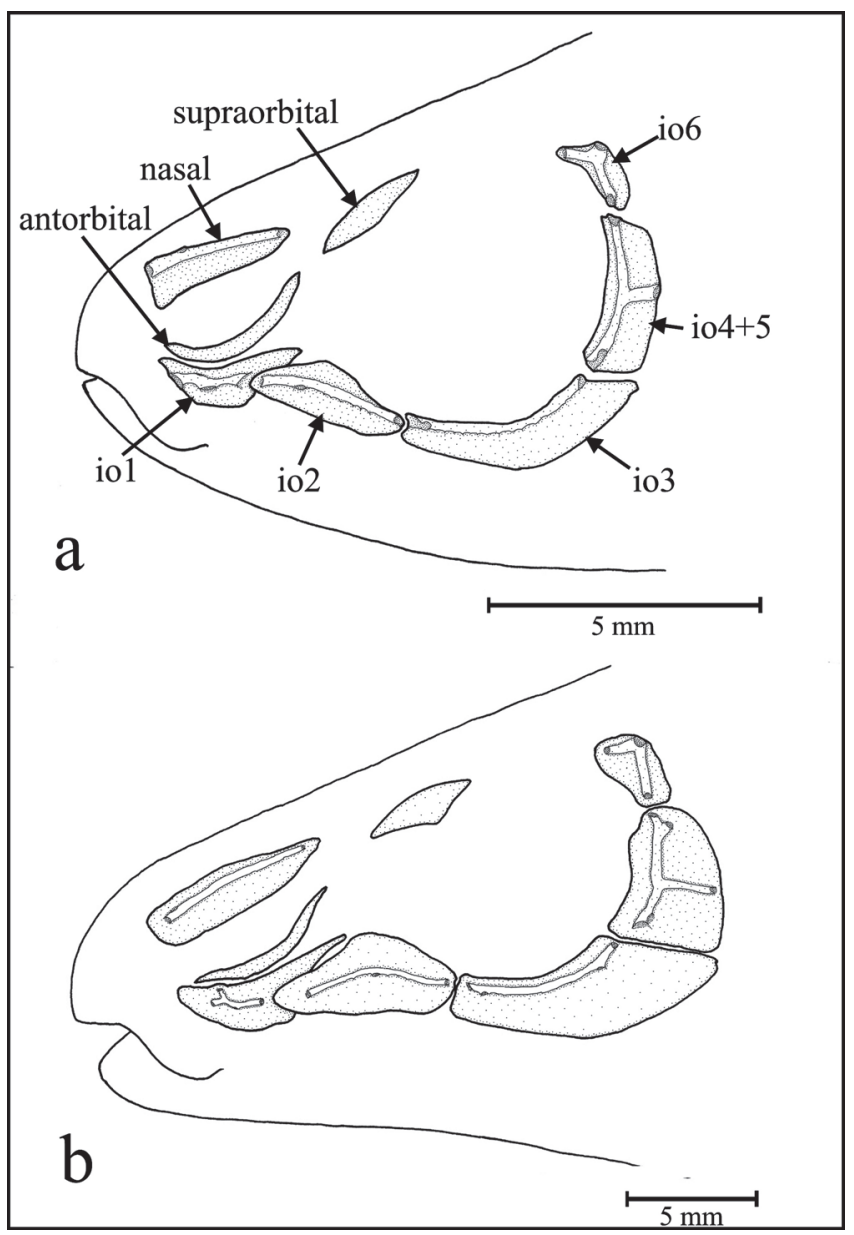

Fig. 9. Lateral view of head of Leporinus reticulatus, a paratype, MZUSP 44782, 52.4 mm SL, b - MZUSP 99734, 111.0 $\mathrm{m} \mathrm{SL}$. io $=$ infraorbitals.

more ventral (than posterior one), directed to the mouth opening, and the associated second infraorbital shifts to a more or less parallel position (relatively to body axis) with the anterior portion longer than the posterior one (Fig. 9b). The most outstanding change is the increased thickness of the lips, and of the anterodorsal portion of the skin over the head.
The fourth and fifth infraorbitals are fused in the two examined clear and stained specimens of L. reticulatus. This is a rather uncommon feature for Leporinus, as several examined species does not possess such characteristic (i.e., $L$. amblyrhynchus, L. desmotes, L. fasciatus, L. friderici, L. julii, L. macrocephalus, L. obtusidens, L. striatus, L. trifasciatus). Leporinus guttatus and L. octomaculatus were the only other examined species that showed such fusion, what make this another interesting feature shared between these species. This feature is also present in L. megalepis and L. despaxi (Sidlauskas \& Vari, 2008: 9), species with subinferior mouth as L. guttatus, L. octomaculatus, and L. reticulatus.

Comparative examined material. All lots from Brazil. Leporinus amblyrhynchus: MZUSP 86196 (1 cs, 101.0 mm SL), Paraná, Tibagi, rio Barra Grande. Leporinus desmotes: MZUSP 91895 (1 sk, 82.0-97.0 mm SL), Mato Grosso, Campinápolis, rio Culuene (134'ㅇ $\left.53^{\circ} 15^{\prime} \mathrm{W}\right)$. Leporinus fasciatus: MZUSP 29139 (1 cs, $80.0 \mathrm{~mm}$ SL), Amazonas, rio Negro, Ilha de Buiu-Açu. Leporinus friderici: MZUSP 58046 (2 cs, 61.7-84.8 mm SL), Pará, Paraupebas, Igarapé Cinzento. MZUSP 91807 (1 sk, 143.0-180.0 mm SL), Goiás, Minaçu, rio Tocantins, UHE Serra da Mesa. MZUSP 95920 (5 sk, 190.0-240.0 mm SL), Mato Grosso, Itaúba, rio Teles Pires (11³'44"S 5519'8'W). MZUSP 94461 (1 sk, 240.0 mm SL), Mato Grosso, Gaúcha do Norte, rio Culuene (1330'53"S 53ㄷ' 40"W). MZUSP 95508 (1 sk, $263 \mathrm{~mm} \mathrm{SL}$ ), Mato Grosso, Sapezal, rio Papagaio (1246’4”S 58²3'5’W). MZUSP 94869 (1 sk, $195.0 \mathrm{~mm} \mathrm{SL})$, Mato Grosso, Campinápolis, rio Culuene

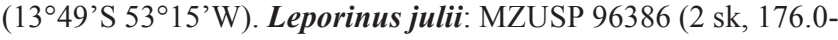
206.0 mm SL), Pará, Novo Progresso, rio Jamanxim (743’51”S 5516’36”W). MZUSP 94866 (1 sk, 141.8 mm SL), Campinápolis, rio Culuene $\left(13^{\circ} 49^{\prime} \mathrm{S} 53^{\circ} 15^{\prime} \mathrm{W}\right)$. Leporinus macrocephalus: MZUSP 89501 ( 1 sk, 340.0 mm SL), Mato Grosso, Barra do Bugres, rio Paraguay. Leporinus marcgravii: MZUSP 73657 (1, $74.4 \mathrm{~mm}$ SL), Minas Gerais, Presidente Juscelino, rio Cipó. MZUSP 73706 (1, 90.7 mm SL), Minas Gerais, Cardeal Mota, rio Cipó. MNRJ 21587 (3, 94.6-118.5 mm SL), Minas Gerais, Jaboticatubas, córrego do Engenho. MCP 28236 (5, 31.1-71.7 mm SL), Minas Gerais, Guarda-Mor, ribeirão Campo Alegre, rio Arrenegado drainage (1755'19"S 475'3"W). Leporinus microphthalmus: MZUSP 38535 (1, $86.0 \mathrm{~mm} \mathrm{SL}$ ), holotype, Minas Gerais, Nova Ponte, rio Araguari, Salto de Nova Ponte. MZUSP 14457 (2, 106.7-107.2 mm SL), paratypes, Goiás, Rio Verde, córrego das Pedras, Fazenda das Pedras. MZUSP 38536 (1, 112.2 mm SL), paratype, Goiás, Três Ranchos, rio Paranaíba, Barragem de Emborcação. MCP 28230 (3, 85.6-94.4 mm SL), Minas Gerais, rio Paranaíba, ribeirão de Fora, (19¹1'58'S 46²1'49”W). MCP 28233 (1, 93.7 mm SL), Minas Gerais, Abadia dos Dourados, creek in rio Paranaíba drainage (18 12 '47'S 47²7'57'W). Leporinus cf. microphthalmus: MZUSP 41837 (2, 77.7-100.1 mm SL), Goiás, Santa Rita do Araguaia, córrego Jóia (17²0'S 5312'W). Leporinus obtusidens: MZUSP 9646 ( 1 cs, 74.4 mm SL), no data. Leporinus octomaculatus (rio Tapajós basin): MZUSP 44794 (1, $67.3 \mathrm{~mm} \mathrm{SL}$ ), holotype, MZUSP 44795 (2, 47-61.1 mm SL), paratypes, Mato Grosso, Nobres, riacho Formoso, Fazenda Sonho Dourado (14 $25^{\prime} \mathrm{S}$ 55 50’W). MZUSP 62591 (12, 62.4-129.0 mm SL), Mato Grosso, Cláudia, creek in Teles Pires drainage. MZUSP 77325 (2, 25.0-26.7 $\mathrm{mm}$ SL), Mato Grosso, Porto dos Gaúchos, rio Arinos. MZUSP 77741 (2, 36.4-36.9 mm SL), Mato Grosso, Juruena, rio Juruena. MZUSP 93701 (11, 74.2-86.0 mm SL), Mato Grosso, rio Papagaio, 
Fazenda Savocal (1246’4'S 58²3'5'W). MZUSP 95778 (4, 111.3$122.9 \mathrm{~mm} \mathrm{SL})$, Mato Grosso, Itaúba, creek in rio Teles Pires drainage

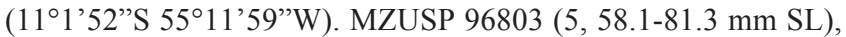
Mato Grosso, Peixoto de Azevedo, rio Peixoto de Azevedo, Cachoeira da Neblina (10²3'10"S 5418'22"W). Leporinus octomaculatus (rio Paraguay basin): MZUSP 78779 (12, 86.8$108.9 \mathrm{~mm}$ SL, $1 \mathrm{cs}, 90.7 \mathrm{~mm}$ SL), Mato Grosso, Reserva do Cabaçal, rio Cabaçal (159'31'S 58²0’36”W). MZUSP 78751 (1, $97.3 \mathrm{~mm}$ SL), Mato Grosso, Porto Estrela, rio Saloba (15³9'3”S 57¹3'29'W). MZUSP 78888 (1, 100.3 mm SL), MZUSP 78890 (1, 104.7 mm SL), MZUSP 78891 (1, $93.1 \mathrm{~mm}$ SL), MZUSP 78893 (1, $05.1 \mathrm{~mm}$ SL), MZUSP 78894 (1, $109.1 \mathrm{~mm}$ SL), MZUSP 78896 (2, 97.4-103.7 mm SL), MZUSP 78901 (1, 54.0 mm SL), MZUSP 78903 (1, $87.1 \mathrm{~mm}$ SL), Mato Grosso, Porto Estrela, rio Saloba. MZUSP 78868 (3, 19.1-24.0 mm SL), Mato Grosso, Diamantino, rio Paraguay, PCH Diamantino (14²8'32"S 56²3'32”W). MZUSP 78887 (1, $106.1 \mathrm{~mm} \mathrm{SL})$, Mato Grosso, Tangará da Serra, córrego da Ponte. MZUSP 78898 (1, 81.7 mm SL), MZUSP 78899 (3, 82.4-87.9 mm SL), Mato Grosso, Porto Estrela, rio Saloba. MZUSP 83599 (1, 44.7 mm SL), Mato Grosso do Sul, Coxim, ribeirão dos Veados, rio Taquari (18²5'21"S 5450'6”W). MZUSP 87787 (1, $103.2 \mathrm{~mm} \mathrm{SL})$, Mato Grosso, Rio Sepotuba, rio Sepotuba (1555'59”S 57³9’00”W). MZUSP 89984 (13, 87.2-104.9 mm SL), Mato Grosso, Tangará da Serra, rio Sepotuba, Salto das Nuvens (14³7’15”S 5744’20”W). MZUSP 90490 (3, 17.7-32.4 mm SL), MZUSP 90245 (1, $44.3 \mathrm{~mm} \mathrm{SL})$, rio Sepotuba (15³1'1'S 5742'26”'W). Leporinus reticulatus: MZUSP 44781 (1, 66.2 mm SL), holotype, MZUSP 44782 (11, 37.3-71.9 mm SL, 1 cs, 52.4 $\mathrm{mm} \mathrm{SL})$, paratypes, Mato Grosso, Nobres, riacho Formoso, Fazenda Sonho Dourado (14²5'S 55 50 ' W). MCP 30437 (4, 70.7$96.0 \mathrm{~mm} \mathrm{SL}$ ), Mato Grosso, riacho Taporah. MZUSP 99734 (3, 107.9-135.9 mm SL, 1 cs, $111.0 \mathrm{~mm} \mathrm{SL),} \mathrm{Mato} \mathrm{Grosso,} \mathrm{Sapezal,}$ rio Juruena, upstream of UHE Juruena. MZUSP 99735 (4, 88.2$106.6 \mathrm{~mm} \mathrm{SL}$ ), Mato Grosso, Sapezal, rio Juruena, upstream of PCH Jesuíta (13¹9’24”S 59¹'49”W). MZUSP 99736 (7, 31.0$135.6 \mathrm{~mm} \mathrm{SL}$ ), Mato Grosso, Campos de Júlio, rio Juruena, Fazenda Tiroleza (14¹6’38'S 59॰5'22”W). MZUSP 99737 (1, 43.8 mm SL), Mato Grosso, Sapezal, Rio Juruena, upstream of PCH Cidezal (13²2'40”S 59¹'1'W). MZUSP 99738 (1, 39.9 mm SL), Mato Grosso, Sapezal, rio Juruena, upstream of PCH Santa Lúcia (1337'55”S 59॰3’3”W). MZUSP 99739 (5, 36.8-72.4 mm SL), Mato Grosso, Sapezal, rio Juruena, upstream of Ilha Comprida (13¹2'11"S 5859'4”W). MZUSP 99740 (1, 96.2 mm SL), Mato Grosso, Sapezal, rio Juruena, downstream of PCH Ilha Comprida (1311'32"S 58०58'51"W). Leporinus striatus: MZUSP uncatalogued (1 cs, $73.7 \mathrm{~mm} \mathrm{SL}$ ), no data. Leporinus trifasciatus: MZUSP 89502 ( 1 sk, 238.0 mm SL), Amazonas, Manaus, Porto do Ceasa (fish market).

\section{Acknowledgements}

We are grateful to Cristiano R. Moreira, Flávio C. T. Lima, Brian Sidlauskas and an anonymous reviewer for comments and suggestions to the manuscript. For loan we thank Mark Sabaj Pérez (ANSP), and Marcelo Rocha and Lúcia RapPyDaniel (INPA). We are grateful to Leandro M. Sousa, André Netto Ferreira, Mark Sabaj Pérez, Nathan Lujan and Pedro Hollanda Carvalho for their help and assistance during the field expeditions. Specimens used in this study were collected during expedition to Serra do Cachimbo, a joint collaboration of MZUSP, ANSP, and AUM, funded by All Catfish Species Inventory (NSF DEB-0315963). We also thank Keve de Silimon for collecting and depositing at MZUSP recently collected specimens of Leporinus reticulatus, and Leandro M. Sousa for designing the map. Authors were financially supported by FAPESP (grant 06/53737-7 - JLOB) and CNPq (HAB).

\section{Literature Cited}

Birindelli, J. L. O., A. M. Zanata, L. M. Sousa \& A. L. NettoFerreira. 2009. New species of Jupiaba Zanata (Characiformes: Characidae) from Serra do Cachimbo, with comments on the endemism of upper rio Curuá, rio Xingu basin, Brazil. Neotropical Ichthyology, 7(1): 11-18

Borodin, N. A. 1929. Notes on some species and subspecies of genus Leporinus Spix. Memoirs of the Museum of Comparative Zoology, 50(3): 268-191.

Britski, H. A. \& J. L. O. Birindelli. 2008. Description of a new species of the genus Leporinus Spix (Characiformes: Anostomidae) from the rio Araguaia, Brazil, with comments on the taxonomy and distribution of L. parae and L. lacustris. Neotropical Ichthyology, 6(1): 45-52.

Britski, H. A. \& J. C. Garavello. 1978. Sobre Leporinus octofasciatus Steindachner da bacia do Paraná (Pisces, Anostomidae). Papéis Avulsos de Zoologia, 31(16): 237-250.

Britski, H. A. \& J. C. Garavello. 1993. Descrição de duas espécies novas de Leporinus da bacia do Tapajós (Pisces, Characiformes). Comunicações do Museu de Ciências e Tecnologia da PUCRS, Série Zoologia, 6: 29-40.

Britski, H. A. \& J. C. Garavello. 2003. Family Anostomidae. Pp. 71-86. In: Reis, R. E., S. O. Kullander \& C. F. Ferraris Jr. (Eds.). Check List of the Freshwater Fishes of South and Central America. Porto Alegre, Edipucrs, 729p.

Britski, H. A. \& J. C. Garavello. 2005. Uma nova espécie de Leporinus Agassiz, 1829, da bacia Amazônica (Ostariophysi: Characiformes: Anostomidae). Comunicações do Museu de Ciências e Tecnologia da PUCRS, Série Zoologia, Porto Alegre, 18(2): 75-83.

Fowler, H. W. 1914. Fishes from the Rupununi River, Britsh Guiana. Proceedings of the Academy of Natural Sciences of Philadelphia, 66: 229-284.

Géry, J. 1960a. Contributions a l'étude des poisons Characoïdes $\left(\mathrm{N}^{\circ} 7\right)$ Validité de Leporinus despaxi Puyo et du sous-genre Hypomasticus Borodin. Bulletin du Muséum National d'Histoire Naturelle, 2a. Série, 32(3): 222-229.

Géry, J. 1960b. Contributions a l'étude des poissons Characoïdes $\left(\mathrm{N}^{\circ}\right.$ 8) Un nouveau sous-genre de Leporinus (Erythrinidae, Anostomidae): Leporinops, type Leporinus moralesi Fowler. Bulletin du Muséum National d'Histoire Naturelle, 2a ${ }^{a}$. Série, 32(4): 308-313.

Géry, J. 1977. Characoids of the world. T.F.H. Publications, New Jersey, 672p.

Goulding, M., R. Barthem \& E. Ferreira. 2003. The Smithsonian atlas of the Amazon. Smithsonian Books, Washington, 253p.

Lima, F. C. T. \& J. L. O. Birindelli. 2006. Moenkhausia petymbuaba, a new species of characid from the Serra do Cachimbo, rio Xingu basin, Brazil (Characiformes: Characidae). Ichthyological Explorations of Freshwaters, 17(1): 53-58.

Santos, G. M. \& J. Zuanon. 2008. Leporinus amazonicus, a new anostomid species from the Amazon lowlands, Brazil (Osteichthyes: Characiformes). Zootaxa, 1815: 35-42. 
Sidlauskas, B. L. \& R. P. Vari. 2008. Phylogenetic relationships within the South American fish family Anostomidae (Teleostei, Ostariophysi, Characiformes). Zoological Journal of the Linnean Society, 154: 70-210.

Taylor, W. R. \& G. C. Van Dyke. 1985. Revised procedures for staining and clearing small fishes and other vertebrates for bone and cartilage study. Cybium, 9: 107-109.

Winterbottom, R. 1980. Systematics, Osteology and Phylogenetic Relationships of fishes of the Subfamily Anostominae (Characoidei, Anostomidae). Royal Ontario Museum, Life Sciences Contribution, 123: 1-112.

Accepted February 2009

Published March 31, 2009 